\title{
The implementation of supply chain management theory in practice: an empirical investigation
}

\section{Structured Abstract}

Purpose: There is significant evidence of a divergence between theory and practice in the field of supply chain management (SCM). The purpose of the research described in this paper is to disentangle the rhetoric from the reality in relation to SCM adoption in practice.

Design/methodology/approach: Based on a review of extant theory, the authors posit a new definitional construct for SCM - the Four Fundamentals - and investigated four research questions (RQs) that emerged from the theoretical review. The empirical work comprised three main phases: focussed interviews, focus groups and a questionnaire survey. Each phase used the authors' definitional construct as its basis. While the context of the paper's empirical work is Ireland, the insights and results are generalisable to other geographical contexts.

Findings: The data collected during the various stages of the empirical research supported the essence of the definitional construct and allowed it to be further developed and refined. In addition, the findings suggest that, while levels of SCM understanding are generally quite high, there is room for improvement in relation to how this understanding is translated into practice.

Research limitations/implications: Expansion of the research design to incorporate case studies, grounded theory and action research has the potential to generate new SCM theory that builds on the Four Fundamentals construct, thus facilitating a deeper and richer understanding of SCM phenomena. The use of longitudinal studies would enable a barometer of progress over time to be developed.

Practical implications: The authors' definitional construct supports improvement in the cohesion of SCM practices, thereby promoting the effective implementation of supply chain strategies. A number of critical success factors (CSFs) and/or barriers to implementation of SCM theory in practice are identified, as are a number of practical measures that could be implemented at policy/supply chain/firm level to improve the level of effective SCM adoption. 
Originality/value: The authors' robust definitional construct supports a more cohesive approach to the development of a unified theory of SCM. In addition to a profile of SCM understanding and adoption by firms in Ireland, the related critical success factors and/or inhibitors to success, as well as possible interventions, are identified.

Keywords: supply chain management, theory, practice, implementation.

\section{Introduction}

Since its introduction by management consultants in the early 1980s, the SCM concept has risen to prominence in both academic and commercial circles. A substantial body of academic knowledge has been, and continues to be, developed in the broad SCM domain. Despite a widespread recognition of its potentially positive impact on firm performance, there is significant evidence of divergence between theory and practice in terms of SCM understanding and adoption. For example, Storey et al. (2006) asserted that:

While there is an emerging body of theory which ostensibly offers a relatively coherent and compelling prescriptive narrative, predominant practice is at considerable odds with this conceptualisation (p. 755).

They also recognised that supply chain theory suggests that the chain should be managed from "end-to-end" but noted that "our research found very few examples of this" (p. 763). This focus on end-to-end thinking is instructive given that integration of supply chain processes and information is a central tenet of contemporary SCM thinking.

However, the work of Fabbe-Costes and Jahre (2007) concluded that, "at this point in time it seems that we can confirm that integration is more rhetoric than reality, that it might be more difficult in practice than in theory" (p. 848). Their more recent work (Fabbe-Costes and Jahre, 2008) reinforces this view. A number of other authors have raised serious questions about the real impact of SCM in practice. For example, Cousins et al. (2006) suggested that:

SCM still appears to suffer from an underlying frustration or perception of being largely ignored; practitioners feel they have a great deal of value to add, but the organisation is not concerned with them (p. 699).

More recently, Kotzab et al. (2011, p. 233) noted that "there is a dearth of evidence in relation to the extent to which SCM - as defined in the academic literature - is implemented or even understood in practice". 
In short, there is evidence to suggest that there are - as Storey et al. (2006) put it "substantial gaps between theory and practice" (p. 769). The research described in this paper attempts to provide some insights into this phenomenon and the issues that it raises. In particular, it aims to develop a profile of current levels of understanding and adoption, as well as to identify some of the factors influencing adoption.

Following this introduction, the paper summarises some of the main theoretical themes and issues from the authors' literature review. We then explain how this review informed the development of a new definitional construct (the Four Fundamentals), as well as the development of four specific research questions that our empirical work aims to provide insights into. The paper then describes the authors' overall research design with specific reference to paradigmatic preferences and methodological choices, as well as to the data collection and analysis methods and techniques to be employed. An overview of the way in which the three phases of the authors' empirical research (i.e. focussed interviews, focus groups and the questionnaire survey) was executed is the provided. This leads to a discussion of the main insights generated by the research into the authors' RQs. Finally, some limitations of the current research, as well as some potentially fruitful future research avenues, are identified by way of conclusion.

\section{Literature review: understanding supply chain management}

\section{Themes and issues in SCM}

Embarking on a literature review in the field of SCM is fraught with difficulty. As stated by Cousins et al. (2006):

To an extent, SCM suffers (or benefits) from being studied from a wide range of academic disciplines and diverse theoretical perspectives. On the one hand this encourages a rich and lively debate, but it may also lead to a fragmented literature, with overlapping constructs and a failure to produce consistent findings (p. 701).

Nonetheless, a number of key themes and issues emerged from the authors' review.

First, there is significant evidence that the effective implementation of SCM can result in improvements in the performance of firms. For example, on the basis of a study of 196 firms, Li et al. (2006) concluded that higher levels of SCM practice "can lead to enhanced competitive advantage and improved organizational performance" (p. 107). Similarly, the work of Frohlich and Westbrook (2001) based on a survey of 322 global manufacturers 
strongly supported the hypothesis that companies with the "greatest extent of supplier and customer integration will have the largest rates of performance improvement" (p. 193). This is significant given the centrality of integration in SCM philosophy.

Second, as noted above the integration of processes and data across the supply chain lies at the heart of SCM philosophy. However, Fabbe-Costes and Jahre (2008), based on a systematic review of 38 papers on the subject of supply chain integration (SCI), noted that:

Even though half of the papers of our total sample conclude that SCI has a positive effect on performance, the variety of empirical bases and the research design of the studies suggest that caution is advisable (p. 140).

This advice supports the assertion of Storey et al. (2006) that predominant practice is at odds with theoretical SCI conceptualisations.

Third, a plethora of SCM definitions have been developed in recent years. There is also evidence of differences in emphasis and approach between practitioners depending on their functional backgrounds, level of seniority, business sector and geographical location. Furthermore, the fact that a variety of associated terminologies have been developed over the years has added to the complexity. As noted by Ross (1998), this can limit management's understanding of the SCM concept and the practical effectiveness of its application. As pointed out in a widely cited article by Mentzer et al. (2001, p.2):

Despite the popularity of the term Supply Chain Management, both in academia and practice, there remains considerable confusion as to its meaning.

A specific area of confusion and ambiguity in this context concerns the relationship between SCM and one of its main antecedents - i.e. logistics (see, for example, Lummus et al. (2001). The work of Larson and Halldorsson (2004) proposed a useful model based on four conceptual perspectives of SCM versus logistics. The "traditionalist" view positions SCM in logistics (i.e. SCM is just one small part of logistics) while, in contrast, the "unionist" perspective treats logistics as a part of SCM (i.e. SCM completely subsumes logistics). The "re-labeling" perspective simply renames logistics (i.e. what was logistics is now SCM!). Finally, the "intersectionist" view assigns a primarily strategic role to SCM with logistics assuming a more operational orientation. Given the broad agreement that appears to exist about what is meant by logistics (see, for example, Lummus et al., 2001) these different perspectives suggests that more clarity is required in relation to how SCM is defined. 


\section{Towards a unified definition of SCM: the Four Fundamentals}

The authors' literature review suggests that there is a lack of agreement in relation to how SCM is defined and points to the need for a new and unified definition. Mentzer et al. (2001, p. 2-3) referred to "confusion", "ambiguity" and "a need to examine the phenomena of SCM more closely to define the term and concept"; Croom et al. (2000, p. 68) noted that despite the existence of SCM since the early 1980s, "conceptually the management of supply chains is not particularly well understood" and went on to highlight the necessity for clear definitional constructs; Burgess et al. (2006, p. 704) observed that, "For the term SCM there appears to be little consensus on its definition"; Kathawala and Abdou (2003, p. 141) concluded that SCM "has been poorly defined and there is a high degree of variability in people's minds about what is meant". Stock and Boyer (2009) provided a comprehensive examination of 166 SCM definitions which have appeared in the literature, building on the earlier work of Mentzer et al. (2001). They summarise many of the points made above very well by concluding that:

Without the adoption of a uniform agreed upon definition of supply chain management (SCM), researchers and practitioners will not be able to "advance the theory and practice" of the discipline. An integrated definition of SCM would greatly benefit researchers' efforts to study the phenomenon of SCM and those practitioners attempting to implement SCM (p. 690).

Other scholars, including New and Payne (1995), Saunders (1995), Croom et al. (2000) and Tan (2001) have highlighted the confusing profliferation of overlapping terminologies and meanings. Furthermore, many of the SCM definitions in the literature attempt to provide short (often single-sentence) definitions (see, in particular: CSCMP, 2013; Mentzer et al., 2001). It is the authors' view that the results are, almost inevitably, achievements in verbal and linguistic dexterity rather than definitions which are likely to add clarity from an SCM application perspective.

In this context, the authors present the Four Fundamentals construct in an attempt to concisely, yet comprehensively, define the essence of SCM as opposed to providing yet another simple definition of SCM. In so doing our purpose is to provide deeper meaning to the phenomena. Our work is aimed primarily at a practitioner audience and aims to bring clarity and understanding to the issue. The avoidance of jargon and complex language is an element of this. It also seeks to be a unified definition without which it is difficult to develop 
robust theories that explain SCM phenomena and which facilitate a deeper and richer understanding of SCM principles and practices. In this context, it takes into account the guidance provided by New (1997):

On the one hand, too tight a definition of the supply chain concept artificially closes off productive avenues of development. On the other hand, too loose a definition allows the label to collapse into an amorphous study of everything (p. 16).

Development of the Four Fundamentals construct was not only informed by the authors' literature review; it also seeks to describe the main constituent elements of SCM as well as positioning SCM in the overall corporate strategic framework. Furthermore, it aims to provide a definition which is intelligible irrespective of the functional background, level of seniority, business sector or geographical location of the practitioner. While the author's definitional construct should facilitate the development of more robust theories of SCM in due course, it does not aim to provide a unified theory of SCM. Indeed, as noted by Halldorsson et al. (2007) "the main message in this paper is that there is no such thing as a 'unified theory of SCM'" (p. 292). The respective Fundamentals are shown in Table 1 and are concerned with:

1. Setting SCM objectives (in relation to customer service and financial optimisation);

2. SCM philosophy (based largely on the integration concept);

3. Managing supply chain flows (particularly material, financial and information flows); and,

4. Supply chain relationships (with specific reference to their creation and management).

\section{INSERT TABLE 1 AROUND HERE}

The construct firstly recognises the importance of objectives in providing a clear focus (Fundamental One). From an SCM perspective, the key objectives are:

- To meet or exceed the required or demanded customer service levels in targeted markets/segments; and,

- To optimise total supply chain cost and investment.

This service/cost approach has long been regarded as central to SCM (see, for example, Christopher, 1992). The central tenet of SCM - or what Storey et al. (2006) referred to the "underpinning 'big idea'" (p. 758) - relates to the integration of processes and information 
across the supply chain. Fundamental Two recognises that the various activities in many supply chains were traditionally managed in isolation from each other and, therefore, often operated at cross purposes. This fragmentation resulted in many non-value adding activities (NVAs) - i.e. activities that added cost and/or time without necessarily adding value from a customer perspective. The need to replace these traditional and often highly fragmented supply chain configurations with more integrated architectures is in essence what SCM philosophy is about. Furthermore, for a supply chain to achieve its maximum level of effectiveness and efficiency, the main flows - i.e. material flows, money flows and information flows - throughout the entire chain must be managed in an integrated and holistic manner, driven by the overall service and financial objectives (as articulated in Fundamental One).

In this way, Fundamental Three recognises that putting SCM philosophy - as articulated in Fundamental Two - into practice requires a strong focus on the management of these flows. Finally, the need to replace fragmentation with integration (as advocated in Fundamental Two) and the holistic approach to flow management (as advocated in Fundamental Three) often requires a reappraisal of the way in which both internal and external customer/supplier relationships are created and managed. Finally, Fundamental Four highlights the importance of relationships in the overall SCM paradigm.

\section{Development of research questions}

As noted at the beginning of this paper, the fundamental aim of our research is to disentangle the rhetoric from the reality in relation to SCM understanding and its adoption in practice. It will do so in the specific context of Ireland. Based on this, the related fundamental question is: "What is the real impact of SCM theory in practice?" The following four research questions have been formulated based on this overall question:

RQ1 - What is the current level of understanding of SCM in practice?

RQ2 - What is the current level of adoption of SCM?

RQ3 - What are the critical success factors and/or inhibitors to success in putting SCM theory into practice?

RQ4 - What practical measures could be implemented at policy/supply chain/firm level to improve the level of effective SCM adoption? 
Figure 1 shows how some of the key literature reviewed by the authors specifically informed the development of their four research questions (RQs). The paper now goes on to describe the research design that the authors developed to generate insights into these questions. An important feature of this design involves using the Four Fundamentals to ensure that the empirical findings are continuously related back to the existing body of scholarly knowledge from which this construct is derived.

\section{INSERT FIGURE 1 AROUND HERE}

\section{Research design}

The following sections describe the philosophical and paradigmatic preferences of the authors, before explaining and justifying the overall methodological approach that was adopted. The specific data collection methods and techniques that were used are then introduced in the context of the overall integrated research design developed by the authors. The context in which the research was carried out (i.e. Ireland) is described briefly and an overview of the overall research design provided.

\section{Research philosophy: paradigmatic preferences and positionality}

As noted by Mangan et al. (2004) "the majority of logistics research is, rightly or wrongly, primarily populated by quantitative research viewed through a positivist lens" (p. 575). This assertion is borne out by the reviews carried out by Dunn et al. (1994), Mentzer and Kahn (1995) and Samuel (1997) in the 1990s, and more recently by Sachan and Datta (2005), Frankel et al. (2005), Spens and Kovacs (2006), Guinpero et al. (2008) and Stock et al. (2010).

Attempting to answer the authors' RQs requires that a range of insights be generated by viewing the research problem through different philosophical perspectives. This helps to ensure that the issues being studied are explored holistically and that the disadvantages associated with the adoption of purely positivist or purely interpretivist positions are avoided. This in turn drives the methodological approach adopted - i.e. one which explores the research questions through an appropriate combination of quantitative and qualitative methods. 


\section{Research methodology}

The overall methodology adopted in the research described in this paper is based on methodological pluralism. This involves the use of multiple methodologies to allow a clearer and more detailed picture of the issues being investigated to be developed. It also responds to the many calls in the literature for the generation of deep and rich insights into phenomena associated with the adoption of SCM practices through the use of research designs that incorporate strong qualitative components (see, for example: Mangan et al., 2004; Seuring, 2005; Guinpero et al., 2008; Stock et al., 2010).

However, it is important to emphasise that the use of multiple-method approaches based on the triangulation principle is not in itself what methodological pluralism is about. Rather, it is concerned with the effective use of a range of appropriate methods as part of an integrated research design. The various methodological approaches need to complement each other as integral elements of a cohesive overall strategy. Furthermore, the RQs posed in this research will be addressed using the Four Fundamentals construct as a frame of reference. As noted above, this construct has itself been developed based on the authors' review of the existing body of SCM knowledge. This, and the adoption of combinatory methodological approaches, is aimed at ensuring that the authors' work contributes in a meaningful way to the further development of SCM theory across the range of domains addressed, as well as being of practical value to practitioners and policy-makers

A further important feature of the research methodology adopted by the authors is its emphasis on the effective simultaneous use of inductive and deductive approaches. This is in line with the assertion of Croom et al. (2000) that "we feel that the inductive/deductive dichotomy is best addressed through the constant reflection of empirical against theoretical studies." (p.75).

\section{Research methods and techniques}

New and Payne (1995) suggested that in the field of empirical research in logistics and SCM, significant progress can be achieved by expanding the range of methods employed. Since then, several other logistics and SCM scholars have made similar suggestions with, in particular, many calls for more qualitative studies to generate deeper and richer understandings of key phenomena (see above and, in particular: Mangan et al., 2004; Seuring, 2005; Guinpero et al., 2008; Stock et al., 2010). In the authors' research, information 
generated by focussed interviews and focus groups was used in combination with more quantitative data generated using a questionnaire survey.

It is important to recognise that capturing a range of perspectives is in itself of value as there are few 'rights and wrongs' in a real-world domain such as SCM. In other words, the researcher can generate insights by understanding the points of view of a range of practitioners, based on their experience in a variety of settings. Given the exploratory nature of many of the questions which the research described in this paper attempts to answer, focussed (or semi-structured) interviews have a role to play as part of the overall design. The focus group method is particularly useful for exploring a specific theme in depth and for drawing out precise issues that may be unknown to the researcher. Questionnaire surveys are useful when the research goal is to provide a description of the incidence or prevalence of a phenomenon (Yin, 1994). This is in line with some of the overall research questions being explored - in particular RQ2. For these and other reasons, use of a survey - as one element of an overall mixed-method approach - provides a potentially efficient means of investigating many of the issues under consideration.

\section{Research context}

Ireland is a small, open, trade-dependent nation and between the mid-1990s and 2007 was one of the fastest growing economies in the developed world. During that period of unprecedented economic growth the level of Irish real gross domestic product (GDP) almost doubled in size and the Irish economy was transformed from its historical agrarian and traditional manufacturing base to one increasingly based on the hi-tech and internationally traded services sectors (ESRI, 2005). These "Celtic Tiger" years are reflected in, for example, headlines in The Economist such as: 'Ireland: Europe's tiger economy' and 'Ireland shines' (Economist, 1997); 'Tiger, tiger, burning bright'; and, 'Lessons from the Irish miracle' (Economist, 2004).

Since 2007 there has been a serious contraction in the size of the economy, with crises in the banking and property sectors - as well as high levels of government, corporate and personal debt - contributing to one of the deepest recessionary periods ever seen in any modern economy (ESRI, 2012). This is reflected in more recent headlines in The Economist with a somewhat different tenor such as: 'The emerald shines no longer: Irish eyes are not smiling' 
(Economist, 2010); 'The many stages of grief' (Economist, 2011); and, 'The muck of the Irish' (Economist, 2012).

Nonetheless, Ireland's economy continues to be one of the most open in the world. The high share of combined imports and exports in GDP (for example, over 180\% in 2011) and the continuing high levels of foreign direct investment (FDI) capital inflows are illustrations of this openness (ESRI, 2012). Government policy has a strong emphasis on export-led growth as the key to economic recovery (see, for example, DJEI, 2011). In this context, logistics and SCM are critically important.

A number of other issues combine to make logistics and SCM particularly important in an Irish context (see for example: Forfas, 1995; Sweeney et al., 2008). The country's relatively peripheral location, and the fact that it is an island, results in transportation costs for companies based in Ireland being higher than those in more favourable locations. Furthermore, the corporate taxation regime (in particular the $12.5 \%$ tax rate on service businesses) makes the option of companies establishing business units (profit centres) in Ireland with responsibility for the management of supply chain activities attractive. One of the challenges in this scenario is the ability of businesses in Ireland to manage increasingly complex and global supply chain configurations.

\section{Overall research design}

The considerations alluded to above resulted in the development of the overall research design shown in Figure 2. The design comprises three phases: (I) focussed interviews; (II) focus groups; and, (III) a questionnaire survey. While each phase aims to address one or two of the RQs specifically, the research has been designed so that all phases can potentially contribute to the generation of insights into all RQs.

\section{INSERT FIGURE 2 AROUND HERE}

RQ1, with a focus on assessing the level of understanding of SCM is - by definition - largely qualitative in nature. A series of semi-structured interviews with key informants, using the Four Fundamentals construct as the basis, provided data to support the effective answering of this question. Additional insights were generated using a series of focus groups comprising decision-makers from key industry sectors. 
As noted above, RQ2 is more quantitative in nature. The Four Fundamentals (built upon and refined based on answering RQ1) was used and the level of SCM adoption measured with reference to its constituent elements. This stage in the process is largely deductive in that a large volume of survey data was analysed to develop a profile of SCM adoption in Ireland. This was supplemented with the deeper and richer insights generated using the focus groups sessions in an inductive manner as appropriate.

Whilst some general ideas may emerge from carefully constructed survey questions, answering RQ3 - as with RQ1 - relied largely on focussed (i.e. semi-structured) interviews with key informants, as well as on focus groups made up of decision-makers from a range of key industry sectors. This facilitated the inductive development of a comprehensive list of critical success factors (CSFs) and/or inhibitors to success using a mix of focussed interviews and focus groups. The qualitative phases of the research (i.e. phases I and II) are largely inductive and exploratory in nature. Whilst the research may not be a theory building process in the classic inductive manner, it attempts to build upon an existing construct (namely the Four Fundamentals) through the development of deep and rich insights into some of its key elements. Answering RQ4 involved a detailed analysis of all primary and secondary data collected during the project. The role of the three phases in the overall research design is shown in Figure 3.

\section{INSERT FIGURE 3 AROUND HERE}

In an effort to address one important aspect of RQ1, in phase I the authors carried out a series of focussed (i.e. semi-structured) interviews aimed at generating some insights into the use of the phrase 'supply chain management' and the word 'logistics'. This involved interviewing managers from two third party logistics providers (3PLs)/distributors, two retailers and two manufacturers, and is to a large extent a replication of the work of Lummus et al. (2001). All interviews were recorded and transcribed. In relation to the analysis of interview transcripts, Easterby-Smith et al. (2008) describe two approaches: content analysis and grounded analysis. The former involves interrogating the data for constructs and ideas that have been decided in advance. The latter involves letting the data "speak for itself" thus allowing for more intuition in guiding the researcher towards an understanding of the data. The authors 
used a combination of both approaches, thus integrating the strengths and mitigating the shortcomings of the two alternatives.

In phase II of the empirical work, the authors used three focus groups in line with the overall research design described earlier. In total, 28 supply chain professionals participated in the authors' focus group sessions: twelve in focus group 1 (FG1); ten in focus group 2 (FG2); and, six in focus group 3 (FG3). Figure 4 shows the breakdown of the groups in terms of broad industry sector. The "manufacturing" category includes firms involved in the food and beverage, pharmaceutical and electrical equipment sectors.

\section{INSERT FIGURE 4 AROUND HERE}

The focus group composition was also set up to ensure that a common frame of reference existed across the three groups as follows:

- both FG1 and FG2 had a representative from a US-headquartered manufacturer of electrical cabling for communications networks (a different person in each case);

- both FG1 and FG3 had a representative from the Irish subsidiary of a large international life sciences group headquartered in the US (again a different person in each case); and,

- $\quad$ FG2 and FG3 had a representative from one large public sector organisation (also a different person in each case).

This ensured a degree of consistency and facilitated comparisons across the three groups. Using a different person from the same organisation in different groups (i.e. as opposed to the same person participating in multiple groups) also maximised the number of views solicited. Each focus group session was facilitated and moderated by a carefully chosen independent person. The sessions were recorded and transcribed. Analysis of the transcripts used a similar approach to that used in the analysis of the focussed interview transcripts in phase I - i.e. a combination of content analysis and grounded analysis.

In phase III of the research the authors distributed a web-based questionnaire to supply chain professionals in just over 1,000 firms in Ireland. The questionnaire comprised 30 questions across six sections, as well as those that relate to demographic and control information and questions were informed by, and followed the logic of, the Four Fundamentals construct. The sampling design used stratified random sampling with stratification based on industry sectors. 
This was achieved using the EU statistical classification of economic activities (NACE Nomenclature générale des Activités économiques dans les Communautés Européennes).

\section{Findings}

The following sections provide an overview of the execution of each of the three main phases of the empirical work.

\section{Phase I: focussed interviews}

The focussed interview results are presented in Table 2 and indicate the use of a variety of emphases and approaches amongst practitioners.

\section{INSERT TABLE 2 AROUND HERE}

The authors' analysis used the Four Fundamentals construct as its basis and provided some useful insights into the issues under investigation. Table 3 summarises the interview findings as they relate specifically to each element of the construct. It also indicates which of the four SCM/logistics perspectives of Larson and Halldorsson (2004) best describes the view of each respondent.

\section{INSERT TABLE 3 AROUND HERE}

In line with the Four Fundamentals of SCM, the authors used the interview findings to develop a model depicting the relationship between SCM and logistics. This was a key output of phase I and is shown in Figure 5. The model is based on distinguishing between internal (or 'micro' or intra-firm) and external (or 'macro' or inter-firm) supply chains. To establish a framework for describing the key functions of a typical internal supply chain, the comment of New (1997, p. 17) that SCM "revolves around the buying, making, moving and selling of 'stuff" " is instructive. For the purposes of the model the authors have added a fifth element, namely the "store" activity. This has been done to ensure that all activities associated with the design and management of warehouses and other storage locations are given due recognition in the framework. Warehouse management has long been regarded as an integral element of the logistics activity of firms and a significant amount of specialist knowledge and expertise in this area has been developed over the years. Essentially, "move" has been disaggregated into separate "move" and "store" elements, reflecting the specific characteristics of each of 
these activities. The wider external chain then represents the flow of material between the firms that comprise the supply pipeline.

\section{INSERT FIGURE 5 AROUND HERE}

For simplicity of illustration the position of the three types of companies interviewed as part of the current research is indicated. In line with the general view of interviewees, the logistics domain is classified as embracing only the "store" and "move" links in the 'micro' (or internal) supply chain. The SCM domain is much broader, including as it does the planning and control of material and other flows through the 'macro' (or external) chain and embracing the "buy", "make" and "sell" links in the internal chain. In this way, the model adopts the unionist perspective of Larson and Halldorsson (2004).

\section{Phase II: focus groups}

Analysis of the focus group discussions provided useful insights into many of the issues under investigation. Notwithstanding the difficulties associated with the transferability of findings from a relatively small sample (i.e. 28 individuals in total), the authors' analysis as it relates specifically to RQ1 suggested that a good understanding of the main elements of SCM was evident from the focus group sessions.

The focus group findings also allowed the authors' Four Fundamentals construct to be refined. This process involved the identification of those key words and phrases used by participants across all three focus groups that were not explicitly part of the authors' original construct. This analysis pointed to the need to more specifically and explicitly acknowledge that environmental sustainability, along with the customer service and financial dimensions already captured in Fundamental One, is in itself a key objective of SCM. This is analogous to the so-called "triple bottom line" approach, a phrase originally coined by and associated with John Elkington (see, for example, Elkington, 1997), and focussed on people (i.e. customer service), profit (i.e. financial) and planet (i.e. environment). A widely cited definition of sustainability is incorporated into the 1987 report of the UN World Commission on Environment and Development (WCED), also known as the Brundtland Commission. This report - Our Common Future (Bruntland Commission (1987) - defines sustainable development as "development that meets the needs of the present without compromising the ability of future generations to meet their own needs" (p. 54). This focus on meeting present 
needs without compromising the future is in essence what the concept of sustainability is about. A slight adaptation of this provides a useful definition of a sustainable supply chain:

A sustainable supply chain is a supply chain that meets the needs of the present without compromising the ability of future generations to meet their own needs.

This definition recognises the fact that business activities can have detrimental effects on the planet's natural systems and encourages all actors in the wider supply chain to adopt policies and practices that promote environmental protection. Based on this analysis, the Four Fundamentals construct was refined by incorporating this sustainability dimension into Fundamental One.

\section{Phase III: questionnaire survey}

There were 132 usable responses received from across the 21 sectors consulted by the authors, representing an overall response rate of $13.1 \%$. A range of statistical tools including significance testing, correspondence analysis factors maps and contingency models were used to analyse the data. These tools allowed a comprehensive profile of SCM adoption in Ireland to be developed. The following section provides one example which illustrates the general analytical approach adopted by the authors.

For example, the first of the questionnaire's six sections was concerned with background issues. For example, question four was a closed question which asked which statement best described the relationship between SCM and logistics. In broad terms the options corresponded to the unionist, traditionalist, re-labeling and intersectionist perspectives proposed by Larson and Halldorsson (2004). Figure 6 (below) shows the relationship between these data and the stated professional backgrounds of respondents. In addition to end-to-end supply chain management, the latter were categorised as: purchasing (including supplier management); production/operations management; transport management; warehouse management; customer service; and, other. Essentially, the first five of these categories correspond respectively to the buy, make, move, store and sell links alluded to earlier and as shown in Figure 5.

\section{INSERT FIGURE 6 AROUND HERE}

The $\chi^{2}$ test suggests that highly (or very) significant differences exist (VS) between respondents from different professional backgrounds. This is largely accounted for by two 
factors. Firstly, the only respondents who suggested that SCM is part of logistics (i.e. the traditionalist perspective) were both from a customer service background. Secondly, a relatively high proportion of the respondents who indicated that SCM was a new name for logistics - albeit just three out of ten - were from a transport management background. These factors can be seen in the factor map of the cross tabulation (see Figure 7) which shows clear linkages between: (i) customer service and "SCM is part of logistics"; and, (ii) transport management and "SCM is a new term for logistics".

\section{INSERT FIGURE 7 AROUND HERE}

A similar analysis was carried out in relation to all variables based on demographic factors (i.e. sector, firm size and firm ownership, in addition to the professional background of respondents as referred to above). These relationships are summarized in the demographic data contingency model in Figure 8. To facilitate clarity, relationships that are not significant (NS) have been omitted. The highly significant dependence between "Relationship between SCM and logistics" and "Respondent Background" alluded to above can be seen in part (a) of the contingency model.

\section{INSERT FIGURE 8 AROUND HERE}

A number of points emerge from an analysis of this contingency model. For example, larger multinational firms and their smaller indigenous peers differ significantly in relation to the SCM practices adopted in a range of areas including the use of customer service audits, measurement of "total supply chain cost" and the use of information and communications technology (ICT) tools. Respondent background also has an impact on the answers provided. This is illustrated by the contrast between, on the one hand, the apparent clarity and certainty that are a feature of the responses of end-to-end supply chain managers and, on the other hand, the ambiguity that characterises some of the responses of function-oriented managers.

Figure 9 shows some of the relationships between variables that relate to Fundamental Two (“Integration"), Fundamental Three ("Flows") and Fundamental Four ("Relationships"). Relationships that are not significant (NS) - this includes all relationships that involved Fundamental One (“Objectives") - have again been omitted to facilitate clarity. 


\section{INSERT FIGURE 9 AROUND HERE}

A number of points emerge from an analysis of this contingency model. For example, there is little evidence to support the conventional view - as articulated in, for example, Kotzab et al. (2011) - that external integration is predicated on the extent of internal integration or that the strength of external relationships is predicated on those of relationships between in-house functions. The dependencies between, on the one hand, the manner in which information flows are managed and, on the other hand, the manner in which material and information flows are managed, is only slightly (or less) significant (LS). A similarly low level of significance exists between the ICT tools used by firms and the manner in which information flows are managed. This challenges the contention that the effective management of material and money flows is predicated upon the effective management of the related information flows, and that ICT is a key enabler of this process. In relation to the latter, there is no significant relationship between ICT tools used in respondents' firms and the extent to which supply chain activities are integrated. This challenges the view - as articulated in, for example, Zhang et al. (2011) - that ICT is a key enabler of SCI. However, there is a highly significant dependence between the extent of internal and external SCI and the manner in which information flows are managed. This suggests that it is the nature of information management rather than the specific ICT tools used that is the critical factor.

\section{Discussion}

The main contributions of the research described in this paper relate to the:

1. Development of a profile of SCM understanding and adoption by firms in Ireland (RQ1 and RQ2), as well as of the related CSFs and/or inhibitors to success (RQ3) and possible interventions (RQ4); and,

2. Development and refinement of the Four Fundamentals definitional construct.

This is in line with two of the possible futures for SCM articulated by Westbrook and New (2004). The former provides insights into the extent to which SCM theory has been adopted in practice by firms (i.e. "realisation"), while the latter supports the development of new thinking in the SCM field (i.e. "rationalisation").

The authors' empirical work provides insights into the level of understanding of SCM in Ireland, with the questionnaire survey also providing a comprehensive profile of the extent of adoption. The key message from this is that, while levels of understanding appear to be quite 
high, the picture is more mixed in relation to actual adoption. This suggests that an "understanding into action conundrum" or an "implementation deficit disorder" exists. This phenomenon is in line with the findings of a recent study by Jin et al. (2013) which revealed that awareness of the competitive potential of SCM practices "is insufficient to mobilize resources and mitigate resistance to collaboration" (p. 205). The CSFs and/or inhibitors to success, along with possible interventions, derived from the current authors' empirical work (see below) facilitate more informed decision making by practitioners and policy makers thus providing a basis for addressing this challenge. Of particular note in this context is the need for definitional clarity that is a major focus of this paper, building on previous work (notably that of Stock and Boyer (2009)).

The need for SCM definitional clarity and consistency among practitioners and researchers as perhaps most succinctly articulated by Stock and Boyer (2009) - is a strong feature of the extant literature. The need for such clarity and consistency was evident in phases I and II and, albeit to a lesser extent, in phase III - of the empirical work. The authors contend that their Four Fundamentals construct squarely addresses this issue. Initially developed based on a wide range of literature, the empirical findings enabled the construct to be refined with: (i) the development and incorporation of a model of the relationship between SCM and logistics based on the focussed interviews of phase I (see Figure 5); and, (ii) the incorporation of a sustainability focus into Fundamental One based on the focus groups of phase II.

The work of Stock and Boyer (2009) examined 173 definitions of SCM that had appeared in the literature up to 2008 "to determine important components of an integrated definition of SCM" (p. 690). Their analysis indicated that three major themes, incorporating six subthemes, occurred repeatedly across these definitions. Table 4 (below) shows how each of these sub-themes is addressed by the Four Fundamentals and indicates that all six are captured in the construct. To put this into context, less than $5 \%$ of the definitions studied by Stock and Boyer (2009) captured all six. This supports the authors' contention that the refined construct concisely, yet comprehensively, defines the essence of SCM, as it has evolved from a variety of disciplines over the last three decades or so.

\section{INSERT TABLE 4 AROUND HERE}


The implications for supply chain professionals at all levels from this research are many and varied. Much of the research described in this paper was driven by calls in the literature for researchers to provide normative guidance to practitioners in terms of SCM implementation (see, for example: Lambert and Cooper (2000); Mentzer at al. (2001); Fawcett et al., 2011). The authors' refined and tested definitional construct is one example of such guidance. By way of addressing RQ3, the authors developed a set of CSFs and/or inhibitors to success in putting SCM theory into practice. These were inductively derived largely from the data collected during the more qualitative elements (i.e. phases I and II) of the empirical research, with some of the survey data playing a role in terms of confirming and/or reinforcing the factors that emerged. They represent another form of normative guidance for practitioners and are shown graphically in Figure 10. They are grouped into logical clusters to facilitate explanation and interpretation.

\section{INSERT FIGURE 10 AROUND HERE}

The top cluster ("Business and Supply Chain Environment") recognises that there are issues beyond the boundary of the firm - i.e. the relative power of firms throughout the supply chain and their lack of a common understanding of what SCM entails - that significantly influence the level of SCM adoption. These are part of what Kotzab et al. (2011) refer to as "joint or external SCM conditions" based on their analysis of ten different frames of reference "to determine the constitutional or antecedent elements of SCM adoption and execution" ( $p$. 233). In practice, this suggests that managers need to at least have an understanding of these external issues and the ways in which they influence the SCM-readiness of a particular organization.

The second cluster ("Company and Management Characteristics") highlights the need for a customer-focused strategic responses that recognise the importance of the people dimension (i.e. the "soft-wiring") and the attendant need to develop appropriate knowledge and skills. These are part of what Kotzab et al. (2011, p. 233) refer to as "internal SCM conditions" as they reside inside an organization. This also recognises the influence of firm demographics (specifically sector and size) on SCM adoption. All phases of the empirical research indicated that larger firms in the hi-tech sectors are more likely to have embraced contemporary SCM practices than their smaller peers in more traditional industries. 
The bottom cluster ("Key Enablers") focuses on two of the critical facilitators of the supply chain change management process. Performance measurement provides a rational basis for continuous improvement across supply chains, with effective information management representing a critical enabler of SCI. As noted earlier, the survey data suggest that the manner in which information is used and shared is the CSF (i.e. rather than the specific ICT tools that are deployed). Improving capability in these two areas is predicated on the necessary knowledge and skills being in place.

With a view to generating insights into RQ4, questionnaire survey respondents were specifically asked about measures that could be adopted to facilitate wider adoption of SCM. The most common response related to education and training with several respondents suggesting that Government support be provided for such initiatives. This, as well as the other four most common responses, is shown in Table 5 with an indication of the relevance of each at the three levels, i.e. policy, supply chain and firm. These possible interventions all also found expression among phase I and II informants to greater or lesser extents.

\section{INSERT TABLE 5 AROUND HERE}

Fawcett and Magnan (2002, p. 359-360) suggested that "SCM practices lack cohesion and visibility" and that "supply chain strategies lack specificity and reach" as a consequence of variations and inconsistencies in understanding. The authors' refined definitional construct, as well as their clusters of CSFs/inhibitors to success, are aimed at improving the "cohesion and visibility" of SCM practices, thereby helping to enhance the "specificity and reach" of supply chain strategies.

\section{Conclusions}

As with all empirical research, our study has certain limitations. The authors adopted a methodologically pluralist approach using focussed interviews, focus groups and a questionnaire survey. This allowed useful insights into the four RQs to be generated but did not allow the questions to be completely answered in a definitive manner. Indeed the nature of the questions is such that they can probably never be answered entirely definitively. Nonetheless, the expansion of the research design to incorporate grounded theory, case studies and action research has the potential to add significantly to the authors' findings. 
The current research (particularly that which relates to RQ1 and RQ2) provides a profile of SCM understanding and adoption in Ireland at a particular point in time. It would be useful for longitudinal studies to be put into place so that a barometer of progress over time could be developed.

The authors' research design incorporated two specific components where horizontal supply chains were studied (i.e. the manufacturing/3PL/retailer configuration in the focussed interviews of phase I and a food industry chain - a manufacturer, a distributor and a retailer that comprised part of FG2 in phase II). While the insights generated from these two components were useful, the amount of work carried out by the authors in this regard was very limited. There is great potential to build on the insights generated by the current research by establishing focus groups that represent horizontal chains.

While the context of the paper's empirical work is Ireland, the insights and results are generalisable to other geographical contexts. Nonetheless, it would be interesting to replicate the study in other countries with a view to identifying points of similarity and points of divergence.

Finally, several implicit and/or explicit concepts that are embraced by the Four Fundamentals construct provide a template of some key elements of good supply chain practice. The construct could, therefore, be further built upon with a view to contributing to the development of new theory that facilitates deeper and richer understanding of SCM.

\section{References}

Brundtland Commission (1987), Our Common Future, World Commission on Environment and Development, Oxford: Oxford University Press.

Burgess, K., Singh, P.K. and Koroglu, R. (2006), 'Supply chain management: a structured literature review and implications for future research', International Journal of Operations \& Production Management, 26(7), 703-729.

Christopher, M. (1992), Logistics and Supply Chain Management: Strategies for Reducing Costs and Improving Service, London: Pitman. 
Cousins, P.D., Lawson, B. and Squire, B. (2006), 'Supply chain management: theory and practice - the emergence of an academic discipline?', International Journal of Operations \& Production Management, 26(7), 697-702.

Croom, S., Romano, P. and Giannakis, M. (2000), 'Supply chain management: an analytical framework for critical literature review', European Journal of Purchasing and Supply Management, 6(1), 67-83.

CSCMP (2013), Council of Supply Chain Management Professionals, http://cscmp.org/about-us/supply-chain-management-definitions [date accessed: July $1^{\text {st }}$ 2013].

DJEI (2011), Department of Jobs, Enterprise and Innovation, Statement of Strategy 20112014, Dublin: DJEI.

Dunn, S.C., Seaker, R.F. and M.A. Waller (1994), 'Latent variables in business logistics research: scale development and validation', Journal of Business Logistics, 15(2), 145-172.

Easterby-Smith, M., Thorpe, R. and Jackson P.R. (2008), Management Research: an introduction, ( $3^{\text {rd }}$ Edition), London: Sage Publications.

ESRI (2005), Economic and Social Research Institute, Annual Report and Review of Research for the Year ended 31 December 2003, Dublin: ESRI.

ESRI (2012), Economic and Social Research Institute, Quarterly Economic Commentary Summer 2012, Dublin: ESRI.

Economist, The (1997), 'Survey: Ireland', 15 May.

Economist, The (2004), 'A Survey of Ireland', 14 October.

Economist, The (2010), 'The emerald no longer shines', 22 November.

Economist, The (2011), 'The muck of the Irish', 31 March.

Economist, The (2012), 'The many stages of grief: the Government's battle to earn respite over its bank bail-outs', 24 March.

Elkington, J. (1997), Cannibals With Forks: the Triple Bottom Line of $21^{\text {st }}$ Century Business, Oxford: Capstone.

Fabbe-Costes, N. and Jahre, M. (2007), 'Supply chain integration gives better performance the emperor's new suit?', International Journal of Physical Distribution \& Logistics Management, 37(10), 835-855.

Fabbe-Costes, N. and Jahre, M. (2008), 'Supply chain integration and performance: a review of the evidence', The International Journal of Logistics Management, 19(2), 130-154. 
Fawcett, S.E. and Magnan, G.M. (2002), 'The rhetoric and reality of supply chain integration', International Journal of Physical Distribution \& Logistics Management, 32(5), 339-361.

Fawcett, S.E., Waller, M.A. and Bowersox, D.J. (2011), 'Cinderella in the C-Suite: Conducting Influential Research to Advance the Logistics and Supply Chain Disciplines', Journal of Business Logistics, 32(2), 115-121.

Forfas (1995), World Class to Serve the World, Dublin: Forfas.

Frankel, R., Naslund, D. and Bolumole, Y. (2005), 'The "white space” of logistics research: a look at the role of methods usage', Journal of Business Logistics, 26(2), 185-208.

Frohlich, M.T. and Westbrook, R. (2001), 'Arcs of integration: an international study of supply chain strategies', Journal of Operations Management, 19(2), 185-200.

Giunipero, L.C., Hooker, R.E., Joseph-Matthews, S.m Yoon, T.E. and Brudvig, S. (2008), 'A decade of SCM literature: past, present and future implications', Journal of Supply Chain Management, 44(4), 66-86.

Halldorsson, A., Kotzab, H., Mikkola, J. H. and Skjott-Larsen, T. (2007), 'Complementary theories to supply chain management', Supply Chain Management: an International Journal, 12(4), 284-296.

Jin, Y.H., Fawcett, A.M. and Fawcett, S.E. (2013), 'Awareness is not enough. Commitment and performance implications of supply chain integration', International Journal of Physical Distribution \& Logistics Management, 43(3), 205-230.

Kathawala, Y and Abdou, K. (2003), 'Supply chain evaluation in the service industry: a framework development compared to manufacturing', Managerial Auditing Journal, 18(2), 140-149.

Kotzab, H., Teller, C., Grant, D.B. and Sparks, L. (2011), 'Antecedents for the adoption and execution of supply chain management', Supply Chain Management: an International Journal, 16(4), 231-245.

Lambert, D.M. and Cooper, M.C. (2000), 'Issues in supply chain management', Industrial Marketing Management, 29(1), 65-83.

Larson, P.D. and Halldorsson, A. (2004), 'Logistics versus Supply Chain Management: An International Survey', International Journal of Logistics: Research and Applications, 7(1), 17-31. 
Li, S., Ragu-Nathan, B., Ragu-Nathan, T.S. and Subba Rao, S. (2006), 'The impact of supply chain management practices on competitive advantage and organizational performance', Omega, 34(2):107-124.

Lummus, R. R., Krumwiede, D. W. and Vokurka, R. J. (2001), 'The Relationship of Logistics to Supply Chain Management: Developing a Common Industry Definition', Industrial Management and Data Systems, 101(8), 426-432.

Mangan, J., Lalwani, C. and Gardner, B. (2004), 'Combining quantitative and qualitative methodologies in logistics research', International Journal of Physical Distribution \& Logistics Management, 34(7), 565-78.

Mentzer, J. and Kahn, K. (1995), 'A framework of logistics research', Journal of Business Logistics, 6(1), 231-50.

Mentzer, J. T., DeWitt, W., Keebler, J. S., Min, S., Nix, N. W., Smith, C. D. and Zacharia Z. G. (2001), 'Defining Supply Chain Management', Journal of Business Logistics; 22(2), 1-25. New, S. (1997), 'The scope of supply chain management research', Supply Chain Management: an International Journal, 2(1), 15-22.

New, S.J. and Payne, P. (1995), 'Research frameworks in logistics: three models, seven dinners and a survey', International Journal of Physical Distribution \& Logistics Management, 25(10), 60-77.

Ross, D. F. (1998), Competing Through Supply Chain Management, New York: Chapman and Hall.

Sachan, A., and Datta, S., (2005), 'Review of supply chain management and logistics research', International Journal of Physical Distribution \& Logistics Management, 35(9), 664-705.

Samuel, D. (1997), 'Research methods explored: an international-based approach', in Proceedings of the Logistics Research Network (LRN) Conference, Huddersfield, September. Saunders, M.J. (1995), 'Chains, pipelines, networks and value stream: the role, nature and value of such metaphors in forming perceptions of the task of purchasing and supply management', in Proceedings of the First Worldwide Research Symposium on Purchasing, Tampe Arizona, March, 476-485.

Seuring, S. (2005), 'Case study research in supply chains - An outline and three examples' in Kotzab, H., Westhaus, M., Seuring, S.A., Muller, M. and Reiner, G. (eds.) Research Methodologies in Supply Chain Management, Heidelberg: Physica-Verlag, pp. 235-250. 
Spens, K.M., Kovacs, G. (2006), 'A content analysis of research approaches in logistics research', International Journal of Physical Distribution \& Logistics Management, 35(2), 132-144.

Stock, J.R. and Boyer, S.L. (2009), 'Developing a consensus definition of supply chain management: a qualitative study', International Journal of Physical Distribution \& Logistics Management, 39(8), 690-711.

Stock, J.R., Boyer, S.L. and Harmon, T. (2010), 'Research opportunities in supply chain management', Journal of the Academy of Marketing Science, 38(1), 32-41.

Storey, J, Emberson, C., Godsell, J and Harrison, A. (2006), 'Supply chain management: theory, practice and future challenges', International Journal of Operations \& Production Management, 26(7), 754-74.

Sweeney, E., Wagner, C. and Huber, B. (2008), 'Supply chain management diffusion among firms in the Republic of Ireland', International Journal of Logistics: Research and Applications, 11(4), 347-358.

Tan, K.C. (2001), 'A framework of supply chain management literature', European Journal of Purchasing and Supply Management, 7(1), 39-48.

Westbrook, R. and New, S. (2004), 'Postscript: Supply Chain Futures', Chapter 12 in Understanding Supply Chains (eds. Westbrook, R. and New, S.), Oxford: Oxford University Press.

Yin, R.K. (1994), Case Study Research, Design and Methods ( $2^{\text {nd }}$ edition), London: Sage Publications.

Zhang, X., van Donk, D.P. and van der Vaart, T. (2011), 'Does ICT influence supply chain management and performance?: A review of survey-based research', International Journal of Operations \& Production Management, 31(11), 1215-1247. 


\begin{tabular}{|l|l|}
\hline Fundamental One & Setting SCM Objectives \\
Fundamental Two & SCM Philosophy: Integration \\
Fundamental Three & Managing Supply Chain Flows \\
Fundamental Four & Supply Chain Relationships \\
\hline
\end{tabular}

Table 1: The Four Fundamentals of SCM 
- Croom et al. (2000): Conceptually the management of supply chains is not particularly well understood.

- Mentzer et al. (2001): Confusion and ambiguity (about SCM). - Kathawala and Abdou (2003): A high degree of variability in people's minds about what is meant (by SCM).

- Lambert (2004): Great deal of confusion regarding exactly what SCM involves.

- Burgess et al. (2006): For the term SCM there appears to be little consensus on its definition.

- Stock and Boyer (2009): Inability to advance the theory and practice.

- Kotzab et al. (2011): Dearth of evidence in relation to the extent to which SCM is even understood.

- Forrester (1958): The 'Forrester Effect' - management on the verge of a major breakthrough.

- New (1997): Normative tension between the is and the ought. - Mentzer et al., (2001): How prevalent is SCM?.

- Leenders et al. (2002): Only in a few leading edge companies. - Storey et al. (2006): Predominant practice is at considerable odds with this conceptualisation.

- Fabbe-Costes and Jahre (2007): Rhetoric and reality.

- Stank et al. (2011): Separate truth from hype.

- Kotzab et al. (2011): Dearth of evidence in relation to the extent to which SCM is implemented.

- Lambert et al. (1999): Need for building theory and developing nomative tools and methods of successful SCM practice.

- Skjoett-Larsen (1999): Nothing is more practical than a good theory.

- Lambert and Cooper (2000): Thus far, there has been relatively little guidance from academia, which in general has been following, rather than leading, business practice.

- Mentzer et al. (2001): Need to give guidance about what SCM is, its prerequisites, and its potential effects on business and supply chain performance.

- Halldorsson et al. (2007): There is no such thing as a 'unified theory of SCM'.

- Stank et al. (2011): Need for deeper insights into complex, multidimensional SCM concepts.
RQ1 - What is the current level of understanding of SCM in practice?<smiles>CCC1CC1(C)C</smiles>

RQ2 - What is the current level of adoption of SCM?<smiles>C1CCCCC1</smiles>

RQ3 - What are the critical success factors and/or inhibitors to success in putting SCM theory into practice?

RQ4 - What practical measures could be implemented at policy/supply chain/firm level to improve the level of effective SCM adoption?

Figure 1: Development of Research Questions 


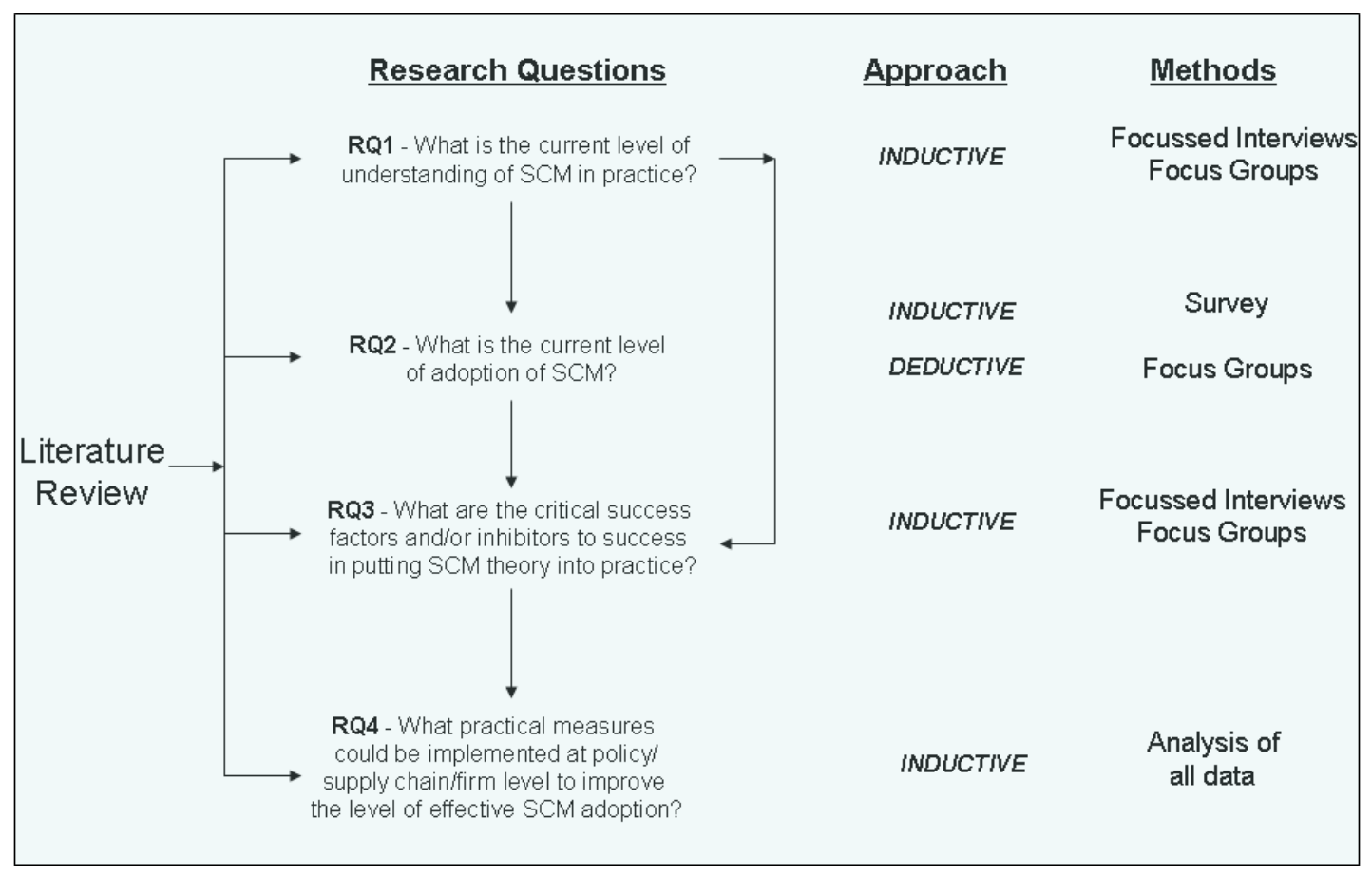

Figure 2: Overall Research Design 


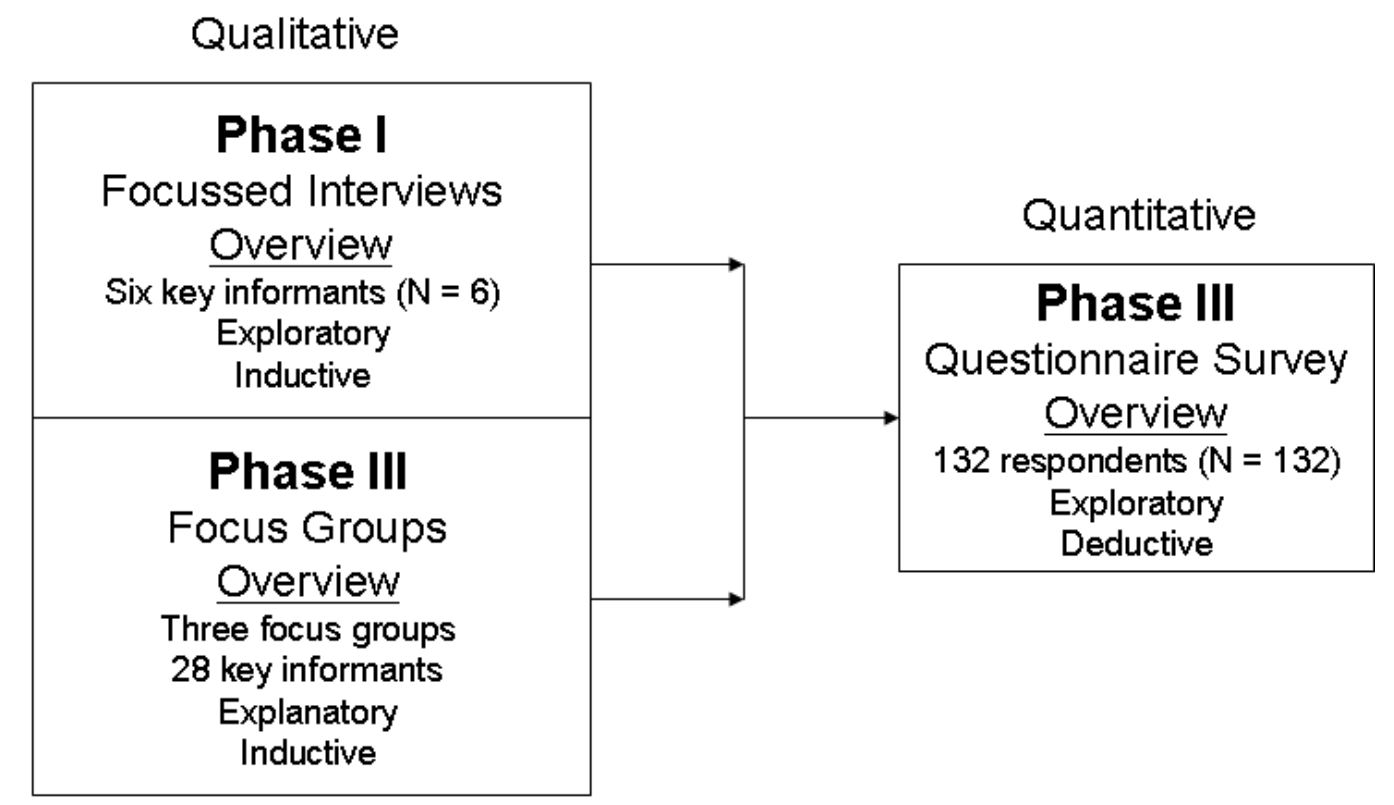

Figure 3: Phases in Overall Research Design 


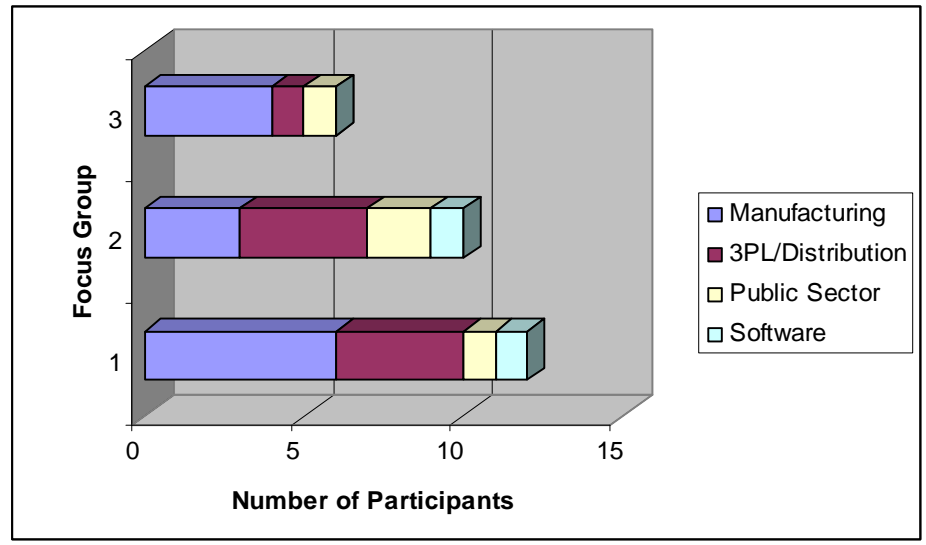

Figure 4: Focus Group Sectoral Breakdown 


\begin{tabular}{|c|c|c|c|}
\hline$\underline{\text { Firm }}$ & $\begin{array}{l}\text { How do you define } \\
\text { supply chain? }\end{array}$ & $\begin{array}{l}\text { How do you } \\
\text { fine logistics? }\end{array}$ & $\begin{array}{l}\text { w are these } \\
\text { eas related? }\end{array}$ \\
\hline Manufacturer 1 & $\begin{array}{l}\text { Supply chain is the network of all } \\
\text { organisations which influence the } \\
\text { reliable and cost effective delivery } \\
\text { of the product or service from the } \\
\text { initial raw material(s) to the end } \\
\text { consumer. } \\
\text { Supply chain management is the } \\
\text { coordination of the individual } \\
\text { processes which manage the flow } \\
\text { of material, money and information } \\
\text { through a network of companies } \\
\text { acting in partnership so that the } \\
\text { overall outcome meets or exceeds } \\
\text { customer needs while minimising } \\
\text { costs throughout the entire chain. }\end{array}$ & $\begin{array}{l}\text { Logistics is the process of } \\
\text { efficiently managing the flow of } \\
\text { material between links along the } \\
\text { supply chain. It includes the } \\
\text { transportation and storage of raw } \\
\text { material, work in process and } \\
\text { finished goods from the ultimate } \\
\text { supplier to the ultimate customer. } \\
\text { It may also include the return flow } \\
\text { of material through the supply } \\
\text { chain for repair or disposal. }\end{array}$ & $\begin{array}{l}\text { Logistics is a subset of supply } \\
\text { chain management. If we take the } \\
\text { earlier definition of supply chain } \\
\text { management as being concerned } \\
\text { with the flow of material, money } \\
\text { and information through the supply } \\
\text { chain then logistics is the execution } \\
\text { phase of the flow of material. } \\
\text { Without efficient logistics then the } \\
\text { supply chain will fail to meet } \\
\text { customer needs in a cost effective } \\
\text { manner. But without efficient } \\
\text { supply chain management } \\
\text { controlling the other flows of } \\
\text { information and money then } \\
\text { logistics will fail to deliver the right } \\
\text { products at the right time to the } \\
\text { right place at the right cost. }\end{array}$ \\
\hline Manufacturer 2 & $\begin{array}{l}\text { The supply chain is the network of } \\
\text { companies (customers and } \\
\text { suppliers) through which the } \\
\text { product passes 'from the farm to } \\
\text { the fork'. It includes farmers, } \\
\text { suppliers, processors, wholesalers, } \\
\text { retailers (and others). }\end{array}$ & $\begin{array}{l}\text { Logistics is physical distribution } \\
\text { management. It is concerned with } \\
\text { movement and storage of products } \\
\text { in the supply chain. }\end{array}$ & $\begin{array}{l}\text { Management of the supply chain is } \\
\text { an aspirational and theoretical } \\
\text { notion. II is about 'end to end } \\
\text { pipeline management' which is not } \\
\text { practical. In practice, SCM is about } \\
\text { managing relationships with key } \\
\text { customers and suppliers. Logistics } \\
\text { is about trucks and sheds', i.e. } \\
\text { management of warehouse and } \\
\text { transport operations. }\end{array}$ \\
\hline 3PL/Distributor 1 & $\begin{array}{l}\text { Supply chain is the pathway from } \\
\text { cradle to grave of products, cradle } \\
\text { being start of process i.e. order } \\
\text { placement of finished product or } \\
\text { sourcing of raw material for } \\
\text { manufacturing etc, grave being } \\
\text { end of process i.e. satisfactory } \\
\text { receipt of invoiced product or } \\
\text { manufactured product ready for } \\
\text { sale. }\end{array}$ & $\begin{array}{l}\text { The processes used in the supply } \\
\text { chain to realise the required result } \\
\text { make up logistics. Source, } \\
\text { transport, information, } \\
\text { manufacture, store etc. Each } \\
\text { process is a stand alone unit in its } \\
\text { own right but must also interface } \\
\text { with other processes to ensure } \\
\text { effectiveness of supply chain. }\end{array}$ & $\begin{array}{l}\text { Logistics are the mechanics or } \\
\text { tools which ensure the } \\
\text { effectiveness of the supply chain, } \\
\text { i.e. for products to move from } \\
\text { source to end user they will move } \\
\text { along the supply chain by way of } \\
\text { logistics process (operations). The } \\
\text { use of these processes as stand } \\
\text { alone units and also how they } \\
\text { interface with each other will } \\
\text { determine the effectiveness of the } \\
\text { supply chain. }\end{array}$ \\
\hline 3PL/Distributor 2 & $\begin{array}{l}\text { Supply chain is the series of } \\
\text { linkages that bring stock or value } \\
\text { from the base raw material to the } \\
\text { end customer. These linkages } \\
\text { traditionally would be the buy, } \\
\text { make, move, sell steps to the end } \\
\text { customer. } \\
\text { Supply chain management focus } \\
\text { on maximising flows of stocks and } \\
\text { services through the chain by } \\
\text { improving the flow of information } \\
\text { and cash through the chain. }\end{array}$ & $\begin{array}{l}\text { Logistics as the process of moving } \\
\text { stock from point to point along the } \\
\text { chain. This process could involve } \\
\text { the use of transport and } \\
\text { warehouses. Logistics is quite } \\
\text { mechanical in that it is instruction } \\
\text { i.e move stock from A to B. }\end{array}$ & $\begin{array}{l}\text { Logistics is a subset of the supply } \\
\text { chain, in that it focused solely on } \\
\text { the storage and movement part of } \\
\text { the supply chain. Logistics is the } \\
\text { mechanical element of moving and } \\
\text { storing in the buy, make move, } \\
\text { store sell model. However, where it } \\
\text { differs from supply chain is that } \\
\text { logistics does not take account of } \\
\text { maximising the information flows or } \\
\text { cash flows within the chain. } \\
\text { Logistics does not seek to find the } \\
\text { weakest link in the chain with a } \\
\text { view to improving it. }\end{array}$ \\
\hline Retailer 1 & $\begin{array}{l}\text { Our primary focus is selling, so } \\
\text { from a retail sector perspective } \\
\text { (the external) supply chain has little } \\
\text { or no relevance to our day to day } \\
\text { operation. Being face to face with } \\
\text { the customer (end user) our only } \\
\text { concern is having the goods } \\
\text { available as and when we need } \\
\text { them - we are not overly } \\
\text { concerned with how products are } \\
\text { produced or in the difficulties that } \\
\text { may ensue in getting them to us - } \\
\text { just so long as we get them on } \\
\text { time; if a supplier fails to deliver } \\
\text { generally we have no difficulty } \\
\text { finding an alternative source. } \\
\text { Of greater concern to us is the } \\
\text { internal supply chain and how } \\
\text { goods / services are managed } \\
\text { within our store environment, that } \\
\text { is from receipt of stock from } \\
\text { suppliers to the delivery / hand } \\
\text { over to our customers. }\end{array}$ & $\begin{array}{l}\text { The internal planning, execution } \\
\text { and control of the movement and } \\
\text { placement of people and/or goods } \\
\text { which results in our customers } \\
\text { receiving the products they require. }\end{array}$ & $\begin{array}{l}\text { Within retail operations they could } \\
\text { be classified as being one and the } \\
\text { same thing. }\end{array}$ \\
\hline Retailer 2 & $\begin{array}{l}\text { In this type of retail business, a } \\
\text { supply chain represents the } \\
\text { network of interconnected activities } \\
\text { from getting raw materials (such as } \\
\text { the mining of diamonds, gold, } \\
\text { culturing of pearls, etc) } \\
\text { transformed into finished pieces of } \\
\text { jewellery that are then sold to end- } \\
\text { consumers. This usually } \\
\text { encompasses discovering and } \\
\text { buying raw materials and energy, } \\
\text { moving (and at times selling) them } \\
\text { to manufacturing locations, } \\
\text { transforming them into finished } \\
\text { products, storing and selling them. } \\
\text { A supply chain can furthermore } \\
\text { consist of goods, services, } \\
\text { information, resources and money. }\end{array}$ & $\begin{array}{l}\text { Logistics in this business can be } \\
\text { defined as to the operational } \\
\text { aspects of transforming unfinished } \\
\text { products into finished goods and to } \\
\text { getting finished or unfinished } \\
\text { products to a desired location in a } \\
\text { predefined time span and to a } \\
\text { certain cost level. }\end{array}$ & $\begin{array}{l}\text { A supply chain is the actual } \\
\text { network of interrelated activities } \\
\text { from getting a raw material into a } \\
\text { finished product including the } \\
\text { associated flow of information, } \\
\text { money etc., whereas logistics is } \\
\text { rather the operational management } \\
\text { aspect of a supply chain with } \\
\text { regards to getting a product, } \\
\text { service, information or resources } \\
\text { from } A \text { to } B \text {. }\end{array}$ \\
\hline
\end{tabular}

Table 2: Observations of Practitioner Respondents 


\begin{tabular}{|c|c|c|c|c|c|}
\hline & $\begin{array}{c}\text { Fundamental } \\
\text { One }\end{array}$ & $\begin{array}{c}\text { Fundamental } \\
\text { Two }\end{array}$ & $\begin{array}{c}\text { Fundamental } \\
\text { Three }\end{array}$ & $\begin{array}{c}\text { Fundamental } \\
\text { Four }\end{array}$ & $\begin{array}{l}\text { Larson and } \\
\text { Halldorsson } \\
\text { (2004) Perspective }\end{array}$ \\
\hline Manufacturer 1 & $\begin{array}{l}\text { - reliable and cost effective } \\
\text { delivery of the product or } \\
\text { service } \\
\text { - meet or exceed customer } \\
\text { needs while minimising } \\
\text { costs throughout the supply } \\
\text { chain }\end{array}$ & $\begin{array}{c}\text { - network of organisations } \\
\text { coordination of individual } \\
\text { processes }\end{array}$ & $\begin{array}{l}\text { - flow of material, money } \\
\text { and information }\end{array}$ & $\begin{array}{c}\text { - companies acting in } \\
\text { partnership }\end{array}$ & - unionist/intersectionist \\
\hline Manufacturer 2 & & - network of companies & & - managing relationships & • unionist \\
\hline 3PL/Distributor 1 & & $\begin{array}{l}\text { - pathway from cradle to } \\
\text { grave of products } \\
\text { - source, transport, } \\
\text { manufacture, store, etc. }\end{array}$ & & $\begin{array}{l}\text { - process interface } \\
\text { management }\end{array}$ & • intersectionist/unionist \\
\hline 3PL/Distributor 2 & $\begin{array}{c}\text { - maximising flows of } \\
\text { stocks } \\
\text { - improving the flow of cash } \\
\text { - creating value }\end{array}$ & $\begin{array}{c}\text { - series of linkages from } \\
\text { raw material to end } \\
\text { customer } \\
\text { - buy, make, move, sell }\end{array}$ & $\begin{array}{l}\text { - flow of stocks, services, } \\
\text { information and cash }\end{array}$ & & - unionist/intersectionist \\
\hline Retailer 1 & - on time delivery & $\begin{array}{l}\text { - receipt of stock from } \\
\text { suppliers to handover to } \\
\text { customers }\end{array}$ & $\begin{array}{l}\text { - placement of people } \\
\text { and/or goods }\end{array}$ & - supplier partnerships & - re-labelling \\
\hline Retailer 2 & $\begin{array}{l}\text { - meeting predefined } \\
\text { delivery targets } \\
\text { - logistics costs }\end{array}$ & $\begin{array}{l}\text { - network of interconnected } \\
\text { activities } \\
\text { - sourcing, buying, moving, } \\
\text { making, storing and selling }\end{array}$ & $\begin{array}{l}\text { - goods, services, } \\
\text { information, resources and } \\
\text { money }\end{array}$ & & - unionist/intersectionist \\
\hline
\end{tabular}

Table 3: Interview Findings and the Four Fundamentals 


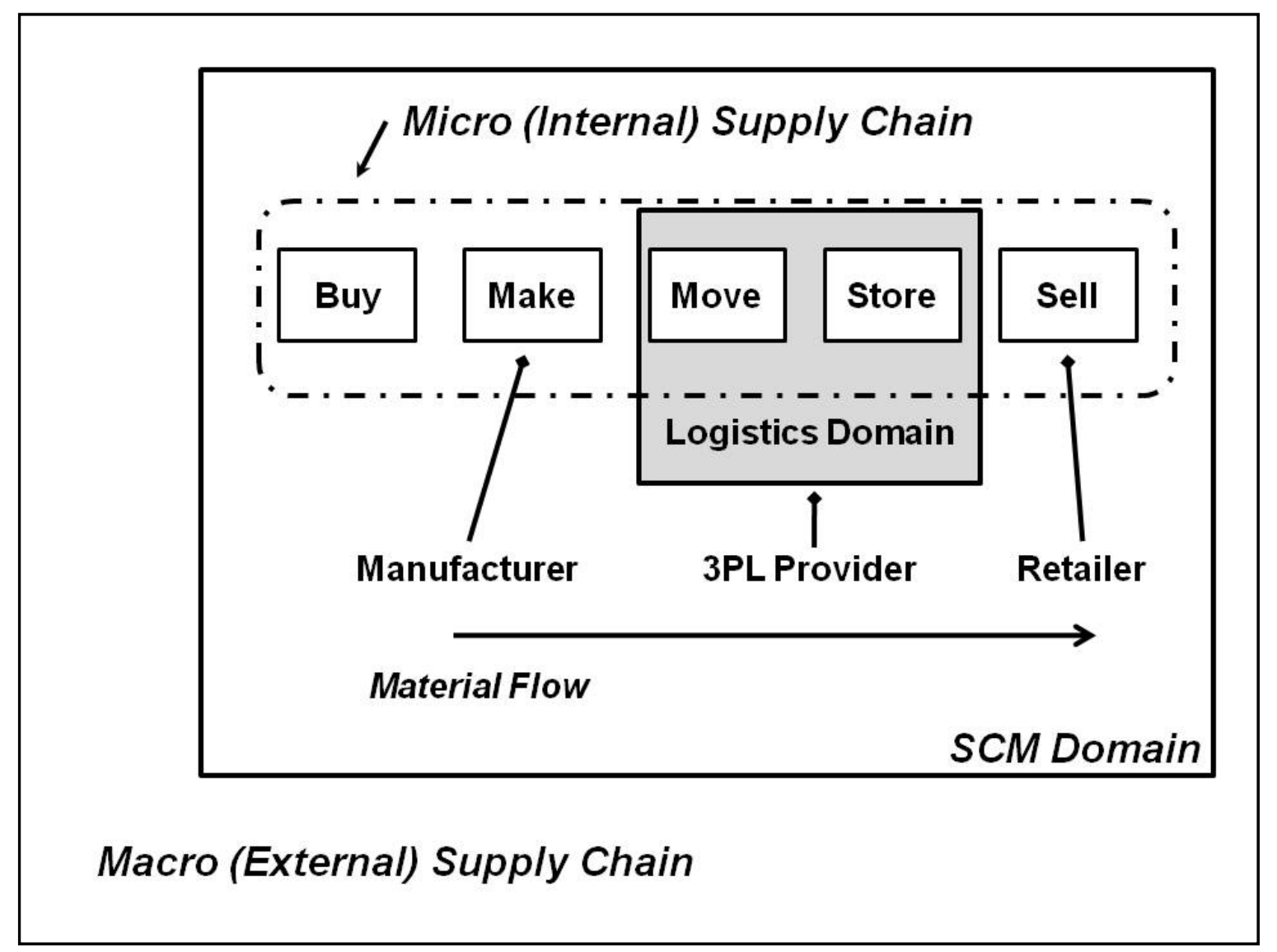

Figure 5: The Supply Chain Management and Logistics Domains 
4. Which of the following staternents best describes the relationship between SCM and logistics? Which of the following best describes your professional background?

\begin{tabular}{|c|c|c|c|c|c|c|c|c|c|c|}
\hline & \multicolumn{2}{|c|}{$\begin{array}{l}\text { SCM is part of } \\
\text { logistics }\end{array}$} & \multicolumn{2}{|c|}{$\begin{array}{l}\text { Logistics is part of } \\
\text { SCM }\end{array}$} & \multicolumn{2}{|c|}{$\begin{array}{c}\text { SCM is a new term } \\
\text { for logistics }\end{array}$} & \multicolumn{2}{|c|}{ Other } & \multicolumn{2}{|c|}{ Total } \\
\hline & $\mathrm{N}$ & $\%$ cit. & $N$ & $\%$ cit. & N & $\%$ cit. & N & $\%$ cit. & N & $\%$ cit. \\
\hline End-to-end supply chain management & 0 & $0.0 \%$ & 44 & $95.7 \%$ & 0 & $0.0 \%$ & 2 & $4.3 \%$ & 46 & $100.0 \%$ \\
\hline Purchasing (including supplier management) & 0 & $0.0 \%$ & 20 & $90,9 \%$ & 2 & $9.1 \%$ & 0 & $0.0 \%$ & 22 & $100.0 \%$ \\
\hline Production/operations management & 0 & $0.0 \%$ & 17 & $85.0 \%$ & 3 & $15.0 \%$ & 0 & $0.0 \%$ & 20 & $100.0 \%$ \\
\hline Transport management & 0 & $0.0 \%$ & 5 & $62,5 \%$ & 3 & $37.5 \%$ & 0 & $0.0 \%$ & 8 & $100.0 \%$ \\
\hline Warehouse management & 0 & $0,0 \%$ & 5 & $83,3 \%$ & 0 & $0,0 \%$ & 1 & $16,7 \%$ & 6 & $100,0 \%$ \\
\hline Customer service & 2 & $25.0 \%$ & 5 & $62,5 \%$ & 1 & $12,5 \%$ & 0 & $0.0 \%$ & 8 & $100.0 \%$ \\
\hline Other & 0 & $0,0 \%$ & 14 & $93.3 \%$ & 1 & $6.7 \%$ & 0 & $0.0 \%$ & 15 & $100.0 \%$ \\
\hline Total & 2 & $1.6 \%$ & 110 & $88.0 \%$ & 10 & $8.0 \%$ & 3 & $2.4 \%$ & 125 & \\
\hline
\end{tabular}

End-to-end supply chain management Purchasing (including supplier management)

Production/operations management

Transport management Warehouse management

Customer service

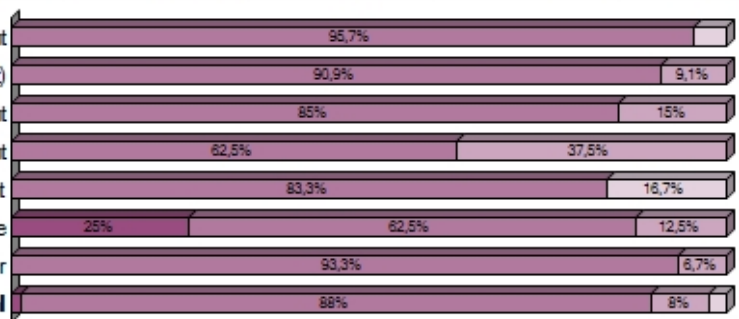

$\mathrm{p}=<0.1 \% ;$ chi2 $=52.77 ;$ dof $=18$ (VS)

Dependence is highly significant.

Figure 6: Relationships Between SCM and Logistics by Respondent Background 


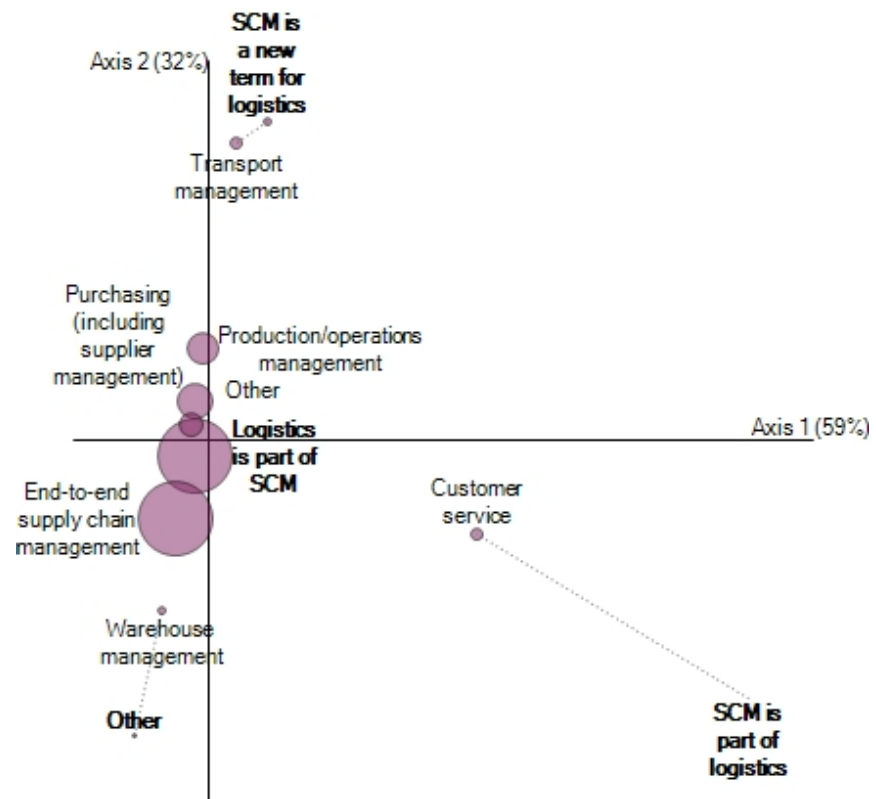

Figure 7: Factor Map - Relationships Between SCM and Logistics by Respondent Background 


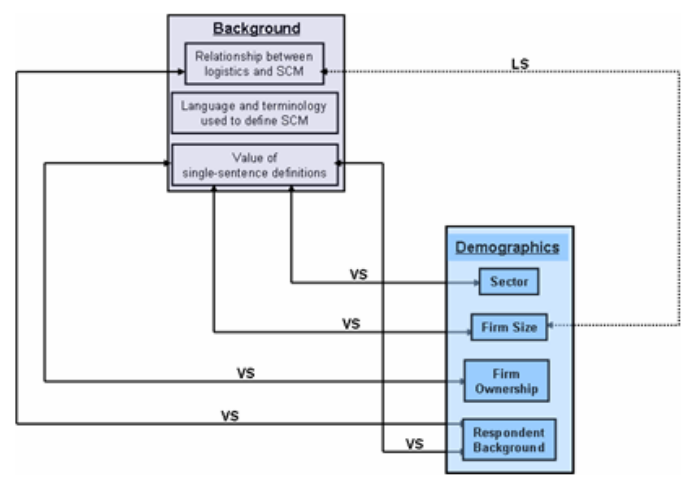

(a) Background
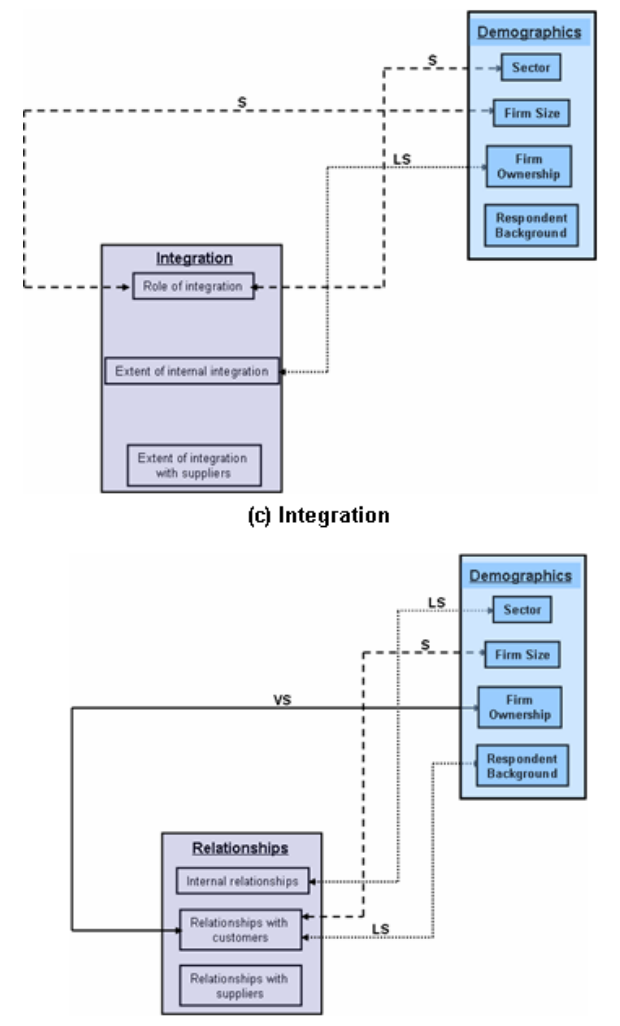

(e) Relationships

$\longleftrightarrow$ vs: Highly Significant

$\leftrightarrow-\cdots$ s: Significant

+....... LS Slightly Significant

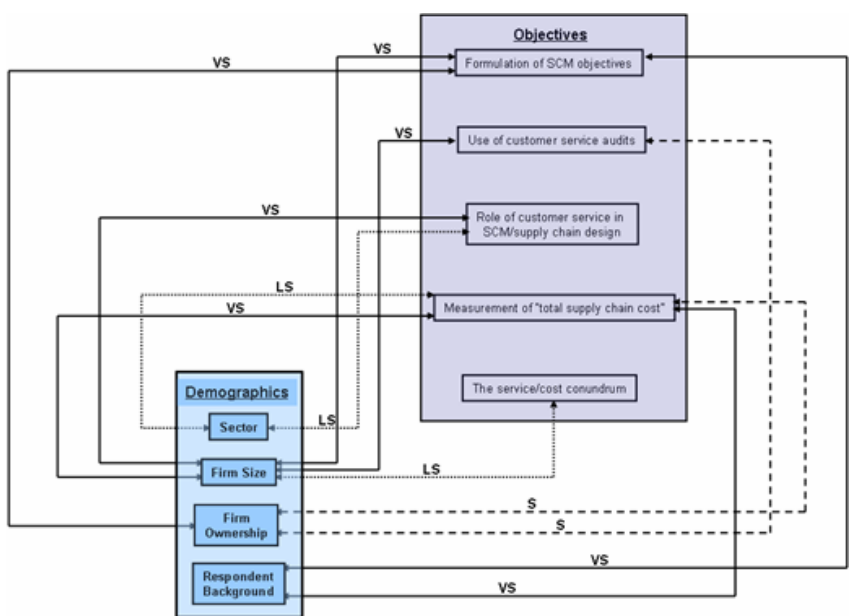

(b) Objectives

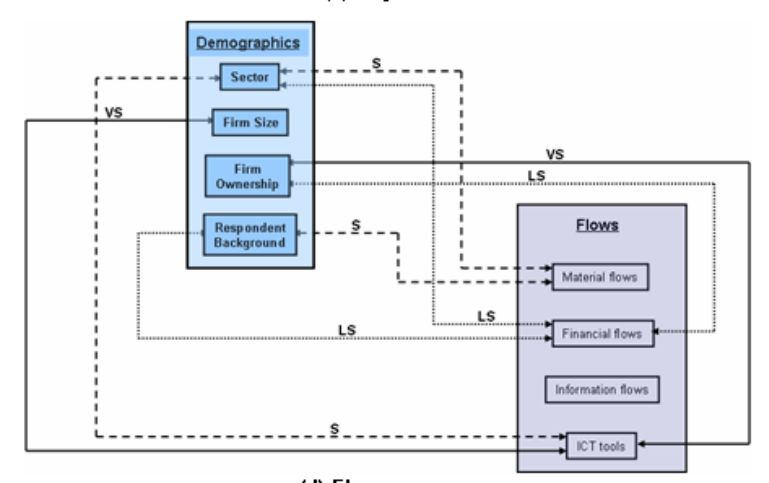

(d) Flows

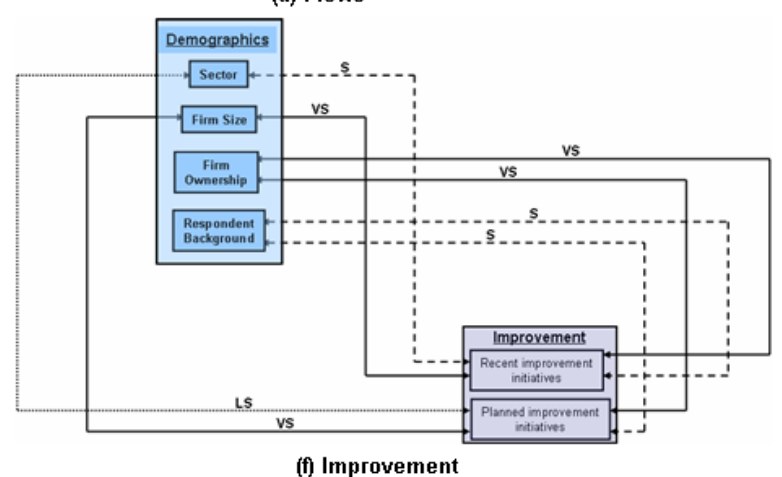

(VS) Highly Significant $p<=1 \%$

(S) Significant: $1 \%<p<=5 \%$

(LS) Slightly Significant 5\%<p 10\%

Figure 8: Demographic Data Contingency Model 


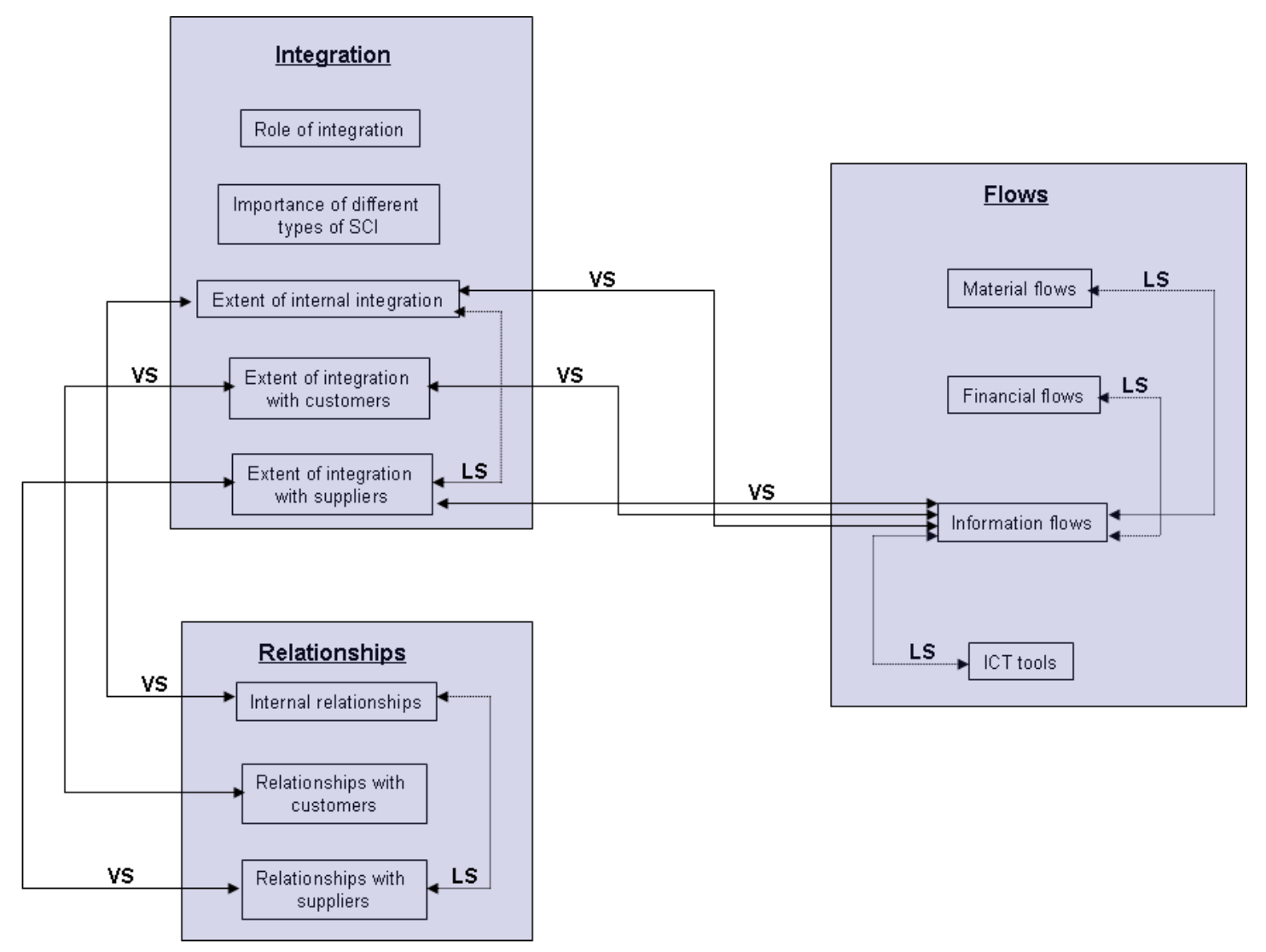

Figure 9: Contingency Model (within and between variable groups) 


\begin{tabular}{|c|c|c|c|c|}
\hline & $\begin{array}{c}\text { Fundamental } \\
\text { One }\end{array}$ & $\begin{array}{c}\text { Fundamental } \\
\text { Two }\end{array}$ & $\begin{array}{c}\text { Fundamental } \\
\text { Three }\end{array}$ & $\begin{array}{c}\text { Fundamental } \\
\text { Four }\end{array}$ \\
\hline $\begin{array}{c}\text { Material/physical, } \\
\text { finances, services } \\
\text { and information } \\
\text { flows }\end{array}$ & & $\mathrm{X}$ & $\mathrm{X}$ & $\mathrm{X}$ \\
\hline $\begin{array}{c}\text { Networks of } \\
\text { relationships }\end{array}$ & $\mathrm{X}$ & & & \\
\hline $\begin{array}{c}\text { Value creation } \\
\text { Creates } \\
\text { efficiencies }\end{array}$ & $\mathrm{X}$ & $\mathrm{X}$ & & \\
\hline $\begin{array}{c}\text { Customer } \\
\text { satisfaction }\end{array}$ & $\mathrm{X}$ & & \\
\hline $\begin{array}{c}\text { Constituents or } \\
\text { components }\end{array}$ & & $\mathrm{X}$ & \\
\hline
\end{tabular}

Table 4: Stock and Boyer (2009) and the Four Fundamentals 


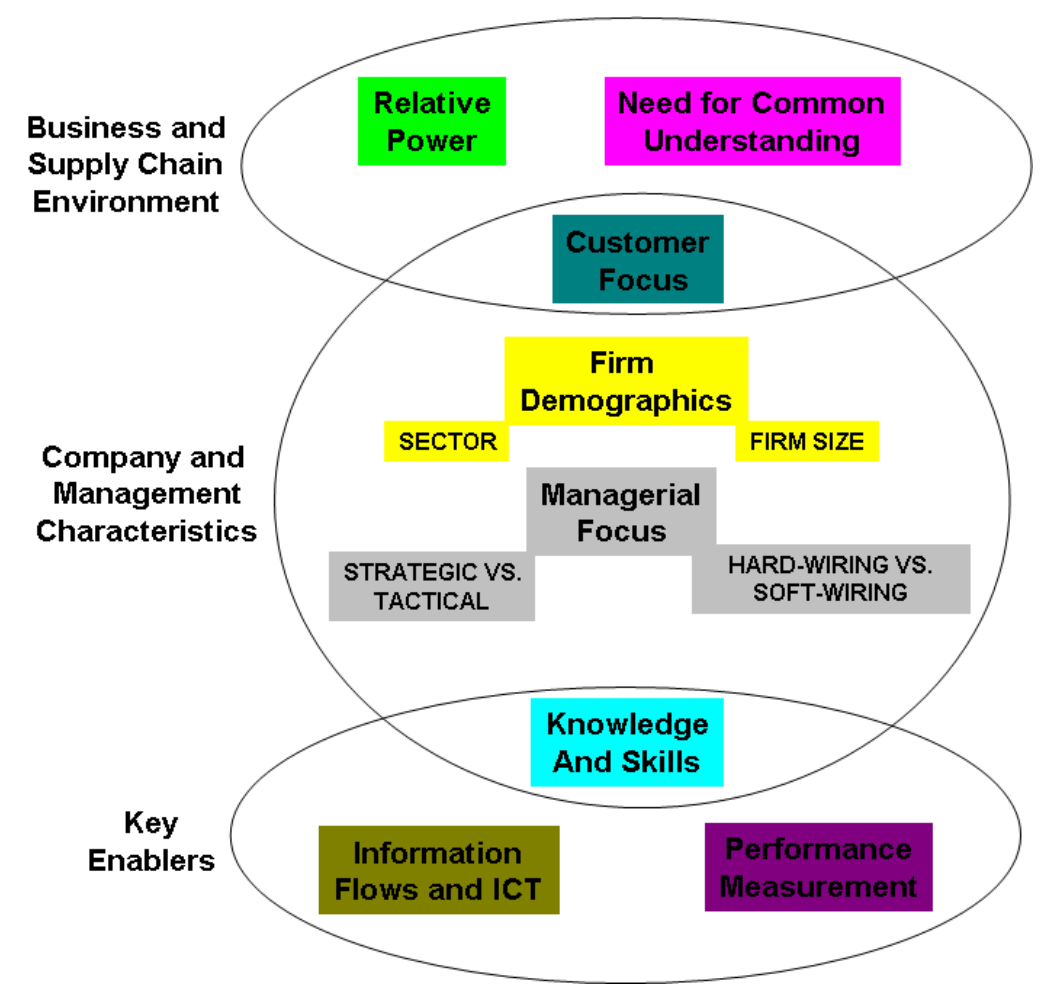

Figure 10: Critical Success Factors and/or Inhibitors to Success 


\begin{tabular}{|c|c|c|c|}
\hline Measure Type/Level & Firm & Supply Chain & Policy \\
\hline Educational & $\mathrm{X}$ & $\mathrm{X}$ & $\mathrm{X}$ \\
\hline Recognition & $\mathrm{X}$ & & \\
\hline Technology & $\mathrm{X}$ & $\mathrm{X}$ & $\mathrm{X}$ \\
\hline Environment & $\mathrm{X}$ & $\mathrm{X}$ & $\mathrm{X}$ \\
\hline Market Information & & & $\mathrm{X}$ \\
\hline
\end{tabular}

Table 5: Possible Measures to Improve SCM Adoption 